\title{
Morphological and Immunohistochemical Studies on Porcine Serum-Induced Rat Liver Fibrosis
}

\author{
Atsushi SHIGA ${ }^{1)}$, Kinji SHIROTA ${ }^{1,3)}$, Teruo IKEDA ${ }^{2,3)}$, and Yasuo NOMURA ${ }^{1)}$ \\ Departments of ${ }^{11}$ Veterinary Pathology, ${ }^{2}$ Veterinary Microbiology, and ${ }^{3}$ Research Institute of Biosciences, School of Veterinary \\ Medicine, Azabu University, 1-17-71 Fuchinobe, Sagamihara, Kanagawa 229, Japan
}

(Received 6 August 1996/Accepted 29 November 1996)

\begin{abstract}
In order to clarify the pathogenesis of porcine serum (PS)-induced rat liver fibrosis, three experiments differing in dose of PS or duration of treatment were performed on male Fischer 344 rats. The rats were given an intraperitoneal injection of PS twice a week for 3 to 16 weeks and euthanized 7 days after the last injection for each treatment group. Liver tissues from these animals were subjected to detailed morphological and immunohistochemical examinations. Biochemical tests on treated rat serum revealed an increase in globulin concentration but no elevation in AST, ALT and ALP activities. There were no relationships among the dose of PS, the extent of fibrosis, and the anti-PS antibody titer. A number of $\alpha$-smooth muscle actin-positive non-myofibroblastic cells, desmin-positive cells, and lipofuscin-laden Kupffer cells were found around the central veins and in the fibrous septa. In advanced stages of fibrosis, a proliferation of elastic fibers were observed in the septa. These findings were considered to indicate gradually occurred hepatocellular necrosis. The vascular endothelial cells in the fibrous septa expressed factor VIII-related antigen, exhibited fenestration accompanied by basement membrane formation, and were surrounded by Ito cells. Most of the portal vein branches showed hypertrophic thickening of the smooth muscle layer, resulting in narrowing of the lumen. These vascular changes suggested that hemodynamic alterations of the intrahepatic circulation induced hepatocellular necrosis/apoptosis and played an important role in the pathogenesis of porcine serum-induced liver fibrosis in rats. - KEY WORDS: immunohistochemistry, liver fibrosis, porcine serum, ultrastructure.
\end{abstract}

J. Vet.Med.Sci. 59(3): 159-167, 1997

Porcine serum (PS)-induced rat liver fibrosis is a unique model of hepatic fibrosis without obvious anteceding parenchymal damage that was established by Paronetto and Popper [27]. A similar type of hepatic fibrosis can be induced in rats by repeated injections of equine serum, egg yolk, and human albumin, but not by treatment with rat serum, human $\gamma$-globulin, or ovalbumin [21, 27]. A variety of studies exploring the effects of chemicals in liver fibrosis has been reported $[12,15,31,35]$. Carbon tetrachloride $\left(\mathrm{CCl}_{4}\right)$-induced rat liver cirrhosis following hepatocellular necrosis has also been used as a model for investigating liver fibrogenesis in comparison with PS-induced fibrosis $[15,22,26]$. Although there have been a number of morphological studies on PS-induced liver fibrosis [1, 3-9, $18,20,22,23,27,32,35]$, its pathogenesis still remains unclear. Previous studies have suggested that host immunoreaction against heterologous proteins appears to be related to this pathogenesis. In studies with mice, immune complexes made the hepatic injuries worse [28]. Popper [29] suggested that hepatocellular necrosis was an important factor for the initiation of liver cirrhosis in humans. The fibrosis in PS-induced model, however, is characterized by absence of obvious hepatocellular necrosis [27], even in the early stage [8]. Moreover, hepatocellular regeneration is also lacking in this fibrosis [32]. The present paper describes the results of morphological and immunohistochemical studies on the pathogenesis of PSinduced fibrosis in rat liver. We tried to demonstrate the presence of hepatocellular necrosis/apoptosis in this model, and time- or dose-related morphological changes associated with fibrosis are discussed.

\section{MATERIALS AND METHODS}

Animals: Fifty, 7-week-old male rats (Fischer 344/NSlc, Japan SLC Inc., Shizuoka), weighing approximately $150 \mathrm{~g}$, were given an intraperitoneal injection of PS (JRH Biosciences, Lunexa, KS, U.S.A., Lot No. 4C2028) twice a week. The same lot of PS was used throughout the study. The rats were housed (two or three per cage) in polycarbonate cages and maintained under controlled conditions (temperature, $23 \pm 2{ }^{\circ} \mathrm{C}$; humidity, $60 \pm 5 \%$ ). A commercial diet (CE-7, CLEA Japan Inc., Tokyo) and tap water were supplied ad libitum. The rats were euthanized under ether anesthesia by exsanguination via the abdominal aorta 7 days after the last injection for each treatment group. The spleen weight was measured to investigate the presence of portal hypertension and the degree of reaction against PS injection, and the mean values for control and treated groups were subjected to statistical analysis with Student's $t$-test. Serum samples, obtained from rats at necropsy, were stored at $-20^{\circ} \mathrm{C}$ until analyses for biochemistry and antibody titer against $\mathrm{PS}$.

Experiment I: This experiment was designed to investigate time-related morphological changes of fibrosis. Rats were injected with a $0.5 \mathrm{~m} l$ of PS twice weekly for 3, $4,5,6$ or 7 weeks. Control rats received $0.5 \mathrm{ml}$ of physiological saline. Two treated rats and two control rats were euthanized at the time points mentioned above.

Experiment II: This experiment was designed to investigate the relationships among dose of PS, extent of fibrosis, and anti-PS antibody titer. Rats were injected with $0.5,1.0$ or $2.0 \mathrm{~m} l$ of PS twice weekly for 8 weeks. Five rats 
were used in each treated group. Five control rats were injected with $0.5 \mathrm{~m} l$ of physiological saline.

Experiment III: This experiment was designed to investigate the morphological characteristics of fullydeveloped hepatic fibrosis with complete septal formation. Five rats were injected with $1.0 \mathrm{~m} l$ of PS twice weekly for 16 weeks. Five control rats were injected with $1.0 \mathrm{~m} l$ of physiological saline.

Enzyme-linked immunosorbent assay (ELISA): Antibody titer against PS in serum from all rats in Experiments I, II and III was measured by ELISA. Microtiter plates (Corning Glass Works, New York, U.S.A.) were coated with PS diluted 1:400 in 0.06 $\mathrm{M}$ carbonate buffer ( $\mathrm{pH}$ 9.6) and nonspecific sites of the plates were blocked with $1 \%$ bovine serum albumin (Sigma Chemical Co., St. Louis, MO, U.S.A.) in phosphate buffered saline containing Tween 20 (PBS-T) (pH 7.4) (Wako Pure Chemical Industries, Ltd., Osaka). Aliquots $(50 \mu l)$ of test sera diluted duplicately in PBS-T were added to the wells and the plates were incubated for $2 \mathrm{hr}$ at $37^{\circ} \mathrm{C}$. The plates were washed five times with PBS-T to remove unbound antibodies. Aliquots $(100 \mu l)$ of peroxidase-conjugated rabbit anti-rat immunoglobulins (DAKO A/S, Glostrup, Denmark) diluted 1:4,000 in PBS-T were added to each well and the plates were incubated for 2 $\mathrm{hr}$ at $37^{\circ} \mathrm{C}$. After incubation, unbound antibodies were removed by washing with PBS-T. Bound antibodies were detected by adding the substrate, O-phenylene diamine (Sigma Chemical Co.) containing hydrogen peroxide. Light absorbance was measured at $492 \mathrm{~nm}$ using an ELISA reader (Seikagaku Kogyo Co., Inc., Tokyo). The anti-PS antibody titer of the treated groups was defined as the highest dilution of serum with an optical density two times higher than that of control rat serum.

Biochemical analysis: Activities of serum AST, ALT and ALP, concentrations of total protein, albumin and globulin, and the albumin/globulin ratio (A/G ratio) in sera obtained from all rats used in Experiments II and III were determined with an automated analyzer (Hitachi 736-10, Hitachi Co., Ltd.). Mean Values of these parameters were subjected to statistical analysis by Student's $t$-test.

Histopathology: All lobes of the liver from each rat in Experiments I, II and III were fixed in 10\% phosphatebuffered formalin, processed routinely, and embedded in paraffin. Histopathological examination except for comparing interlobar difference in extent of fibrosis was mainly performed on the left lateral lobe. Paraffin sections were cut and stained with hematoxylin and eosin (HE) and with special stains including Masson's trichrome stain, periodic acid-Schiff (PAS) reaction with diastase digestion, Schmorl's ferric-ferricyanide reduction stain, Perls' Prussian blue stain, Orcein stain, and toluidine blue ( $\mathrm{pH} \mathrm{4.1)} \mathrm{stain.}$ To detect cytoplasmic lipids in Ito cells, formalin-fixed liver tissue was refixed in Luna's fixative $(50 \mathrm{~m} l$ of $2 \%$ osmium tetroxide, $50 \mathrm{ml}$ of $5 \%$ potassium dichromate and 10 drops of glacial acetic acid) for 3 days at $4{ }^{\circ} \mathrm{C}$. In addition, the number of mitotic hepatocytes in the left lateral lobe tissue sections of control and treated rats from Experiments II and III was counted. In Experiment II, the extent of fibrosis in each lobe of the liver was classified in 4-grades (Grades 1: early stage; Grades 2 and 3: late stage: Grade 4: advanced stage) following to Fujiwara et al. [12] to facilitate interlobar comparison. To compare the extent of hepatic fibrosis in between individual rats, the left lateral lobe of each liver was investigated. Histological examination of the spleen was also performed to evaluate the degree of follicular hyperplasia.

Immunohistochemistry: Immunohistochemical examination of rat liver showing each stage of fibrosis was performed by the labeled streptavidin-biotin method using a Histofine kit (Nichirei Corp., Tokyo). Representative liver tissue from 2 rats in each stage was investigated. Primary antibodies used in the present study are shown in Table 1. The antibodies, except for vimentin, were applied to formalin-fixed, paraffin- embedded tissues. In the case of vimentin, methacarn (60\% methanol, $30 \%$ chloroform, $10 \%$ glacial acetic acid) was used as fixative. After blocking endogenous peroxidase activity with $3 \%$ hydrogen peroxide in deparaffinized sections, normal rabbit or goat serum was applied to the sections to inhibit nonspecific reactions. The sections were treated with primary antibodies for $1 \mathrm{hr}$ at $37^{\circ} \mathrm{C}$, next with biotinylated rabbit anti-mouse IgG or goat anti-rabbit $\mathrm{IgG}$ for $10 \mathrm{~min}$ at room temperature, then with peroxidase-labeled streptavidin for $15 \mathrm{~min}$ at room temperature, and finally with 3,3 '-diaminobenzidine in 0.1 M Tris buffer ( $\mathrm{pH}$ 7.6) containing hydrogen peroxide. The sections were washed with $0.1 \mathrm{M}$ phosphate-buffered saline (PBS) (pH 7.4) after each step. Counterstaining was performed with Mayer's hematoxylin stain. Immunostaining for proliferating cell nuclear antigen (PCNA) was performed

Table 1. Primary antibodies

\begin{tabular}{|c|c|c|}
\hline Antibody & Source (clone) & General reactivity \\
\hline Anti-desmin (m) ${ }^{\mathrm{a})}$ & $\begin{array}{l}\text { Dakopatts, Denmark } \\
\text { (D33) }\end{array}$ & Ito cells \\
\hline Anti- $\alpha$-SMA (m) & $\begin{array}{l}\text { Sigma Chemical Co., } \\
\text { U.S.A. (1A4) }\end{array}$ & $\begin{array}{l}\text { activated Ito cells, } \\
\text { myofibrobast-like } \\
\text { cells, smooth muscle } \\
\text { cells }\end{array}$ \\
\hline Anti-vimentin (m) & $\begin{array}{l}\text { Dakopatts, Denmark } \\
\text { (V9) }\end{array}$ & $\begin{array}{l}\text { Ito cells, endothelial } \\
\text { cells, Kupffer cells }\end{array}$ \\
\hline $\begin{array}{l}\text { Anti-monocytes/ } \\
\text { macrophages (m) }\end{array}$ & $\begin{array}{l}\text { Serotec, UK } \\
\text { (ED-1) }\end{array}$ & $\begin{array}{l}\text { monocytes, Kupffer } \\
\text { cells }\end{array}$ \\
\hline $\begin{array}{l}\text { Anti-macrophages } \\
\text { (m) }\end{array}$ & $\begin{array}{l}\text { Serotec,UK } \\
\text { (ED-2) }\end{array}$ & Kupffer cells \\
\hline Anti-FVIII-RAg(p) ${ }^{\text {b) }}$ & Dakopatts, Denmark & $\begin{array}{l}\text { vascular endothelial } \\
\text { cells } \\
\left(\text { except for } \mathrm{SECs}^{\mathrm{c})}\right)\end{array}$ \\
\hline Anti-PCNA (m) & $\begin{array}{l}\text { Dakopatts, Denmark } \\
\text { (PC10) }\end{array}$ & $\begin{array}{l}\text { Nuclei of cells in G1 } \\
\text { and } S \text { phase }\end{array}$ \\
\hline
\end{tabular}

a) (m): Mouse monoclonal, b) (p): Rabbit polyclonal. c) SECs: Sinusoidal endothelial cells. 
on left lateral lobe of the liver from rats in Experiment III. Absolute counts of PCNA-immunoreactivity were made by assessing a minimum of 1,000 hepatocytes and were represented as a labelling index (LI).

Electron microscopy: Electron microscopical examination was performed on 2 livers from each group showing Grade 2 or 3 (Experiment II) and Grade 4 (Experiment III) fibrosis. Small blocks $\left(1 \mathrm{~mm}^{3}\right)$ of liver were fixed in $2.5 \%$ glutaraldehyde/0.1 M phosphate buffer $(\mathrm{pH} \mathrm{7.4)}$ ) for $2 \mathrm{hr}$ at $4{ }^{\circ} \mathrm{C}$, post-fixed in $1 \%$ osmium tetroxide $/ 0.2 \mathrm{M}$ phosphate buffer for $2 \mathrm{hr}$ at $4^{\circ} \mathrm{C}$, dehydrated in graded ethanol, and embedded in epoxy resin. Semi-thin sections were cut, stained with toluidine blue, and examined by light microscopy to find the target sites. Then, ultra-thin sections were cut, double-stained with uranyl acetate and lead citrate, and examined using an Hitachi H-300 transmission electron microscope at $75 \mathrm{kV}$.

\section{RESULTS}

Spleen weight: Spleen weight in the treated groups in all experiments showed a significant increase $(\mathrm{p}<0.01$, data not shown), except for the rats treated with $0.5 \mathrm{~m} l$ of PS twice weekly for 8 weeks in Experiment II.

ELISA: Anti-PS antibody was detected in the serum samples obtained from all PS-treated rats in Experiments I, II and III. The anti-PS antibody titer had a tendency to increase in proportion to the duration of injection period (Table 2), however it did not correlate with the dose of PS, as shown in Table 3 . The average antibody titer in 16week-treated rats was one and a half times higher than that in 8-week-treated rats.

Biochemical analysis: As shown in Table 4, in PS-treated groups, no elevation of serum AST, ALT, or ALP activity was observed and the serum albumin concentration was within normal range. However, in PS-treated rats of experiments II and III, the total protein and globulin concentration was statistically higher and the $\mathrm{A} / \mathrm{G}$ ratio was statistically lower than those of the control rats. In addition, the globulin concentration and $\mathrm{A} / \mathrm{G}$ ratio varied in a dose- related manner.

Histopathology: In Experiment I, hepatic fibrosis first appeared at the 5th week post-initial injection (p.i.) of PS (Fig. 1). Most of the early fibrosis developed around central veins (CVs) near the hepatic capsule. Eosinophils occasionally infiltrated around CVs even at this early stage of fibrosis (5th week p.i.), but no mast cells were observed. Likewise, Schmorl reaction and Perls' Prussian blue stain revealed that lipofuscin- and hemosiderin-laden macrophages appeared frequently around CVs (Fig. 1) and in fibrous septa (FS) from the early (5th week p.i.) stage onwards.

Complete septal fibrosis was observed by the 7 th week p.i., though the FS were still very delicate (Fig. 2). Cellular components around CVs and in the FS were spindle cells, mast cells, eosinophils, and macrophages. Luna's fixativerefixed, paraffin-embedded sections demonstrated the presence of a number of cells containing fat droplets in the FS. The walls of the portal vein branches were thickened due to hypertrophy of smooth muscle cells (SMCs), which resulted in narrowing of the lumens (Figs. 3a, b). This vascular change was observed concurrently with the occurrence of fibrosis (5th week p.i.). No remarkable changes were found in the control rat liver.

In Experiment II, there was no clear relationship between the extent of hepatic fibrosis and the dose of PS. The extent of fibrosis clearly varied among rats within each dose group (Table 3). Likewise, the number of mitotic hepatocytes did not correlate with the extent of fibrosis (data not shown). The lesions in the treated rat liver were

Table 2. Time-related change in the anti-PS antibody titer of treated rats

\begin{tabular}{llcccc}
\hline & \multicolumn{5}{c}{ Weeks after initial injection } \\
& 3 & 4 & 5 & 6 & 7 \\
\hline Anti-PS & $1: 800^{*}$ & $1: 1,600$ & $1: 1,600$ & $1: 6,400$ & $1: 6,400$ \\
Antibody & $1: 400$ & $1: 1,600$ & $1: 6,400$ & $1: 12,800$ & $1: 6,400$ \\
\hline
\end{tabular}

* Titer in each rat receiving $0.5 \mathrm{~m} l$ of PS. PS: Porcine serum.

Table 3. Histological grade of hepatic fibrosis and anti-PS titer

\begin{tabular}{|c|c|c|c|c|c|c|c|}
\hline \multirow{2}{*}{$\begin{array}{c}\text { Weeks after } \\
\text { initial } \\
\text { injection }\end{array}$} & \multirow[t]{2}{*}{$\begin{array}{c}\text { Inoculant }^{\mathrm{a})} \\
\text { (volume/injection) }\end{array}$} & \multicolumn{3}{|c|}{$\begin{array}{c}\text { Extent of hepatic } \\
\text { fibrosis }{ }^{b)}\end{array}$} & \multirow[b]{2}{*}{3} & \multirow[b]{2}{*}{4} & \multirow[t]{2}{*}{$\begin{array}{l}\text { Mean titer of } \\
\text { anti-PS antibody }\end{array}$} \\
\hline & & 0 & 1 & 2 & & & \\
\hline \multirow{4}{*}{8} & $\mathrm{~S}(0.5 \mathrm{~m} l)$ & $5^{\mathrm{c})}$ & 0 & 0 & 0 & 0 & negative \\
\hline & $\mathrm{PS}(0.5 \mathrm{~m} l)$ & 0 & 2 & 2 & 0 & 1 & $1: 14,080$ \\
\hline & PS $(1.0 \mathrm{~m} l)$ & 0 & 2 & 0 & 1 & 2 & $1: 14,080$ \\
\hline & $\mathrm{PS}(2.0 \mathrm{~m} l)$ & 1 & 0 & 1 & 1 & 2 & $1: 14,080$ \\
\hline \multirow{2}{*}{16} & $\mathrm{~S}(1.0 \mathrm{~m} l)$ & 5 & 0 & 0 & 0 & 0 & negative \\
\hline & $\mathrm{PS}(1.0 \mathrm{~m} l)$ & 0 & 0 & 0 & 1 & 4 & $1: 20,480$ \\
\hline
\end{tabular}

a) S: Physiological saline, PS: Porcine serum.

b) Literature cited: [12]. O: none. Grade 1: Short collagenous septa extended from central veins. Grade 2: Slender septa link the central veins, but lobular architecture is preserved. Grade 3: Pseudolobuli are formed by thin septa. Grade 4: Parenchyma is subdivided into smaller pseudolobuli by thin septa.

c) Number of rats. 
Table 4. The results of blood biochemistry

\begin{tabular}{|c|c|c|c|c|c|c|c|c|}
\hline $\begin{array}{l}\text { Weeks afte } \\
\text { initial } \\
\text { injection }\end{array}$ & 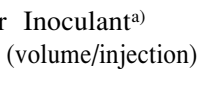 & $\begin{array}{l}\text { AST } \\
(\mathrm{IU} / \mathrm{L})\end{array}$ & $\begin{array}{c}\text { ALT } \\
(\mathrm{IU} / \mathrm{L})\end{array}$ & $\begin{array}{c}\text { ALP } \\
(\mathrm{IU} / \mathrm{L})\end{array}$ & $\begin{array}{c}\text { T.P. } \\
(\mathrm{mg} / \mathrm{d} l)\end{array}$ & $\begin{array}{c}\mathrm{Alb} \\
(\mathrm{mg} / \mathrm{d} l)\end{array}$ & $\begin{array}{l}\mathrm{Glb} \\
(\mathrm{mg} / \mathrm{d} l)\end{array}$ & $\mathrm{A} / \mathrm{G}$ \\
\hline \multirow{4}{*}{8} & $\mathrm{~S}(0.5 \mathrm{ml})$ & $96 \pm 20$ & $53 \pm 12$ & $370 \pm 23$ & $6.33 \pm 0.17$ & $3.63 \pm 0.08$ & $2.70 \pm 0.10$ & $1.35 \pm 0.04$ \\
\hline & $\mathrm{PS}(0.5 \mathrm{~m} l)$ & $76 \pm 5$ & $43 \pm 5$ & $377 \pm 34$ & $6.76 \pm 0.23^{*}$ & $3.79 \pm 0.17$ & $2.97 \pm 0.09 * *$ & $1.28 \pm 0.05^{*}$ \\
\hline & PS $(1.0 \mathrm{~m} l)$ & $74 \pm 8$ & $41 \pm 3$ & $385 \pm 14$ & $6.92 \pm 0.10^{* * *}$ & $3.86 \pm 0.05^{* * *}$ & $3.06 \pm 0.07 * * *$ & $1.25 \pm 0.02 * *$ \\
\hline & PS $(2.0 \mathrm{~m} l)$ & $68 \pm 4 *$ & $36 \pm 3^{*}$ & $344 \pm 45$ & $6.87 \pm 0.15^{* * *}$ & $3.76 \pm 0.09$ & $3.11 \pm 0.13^{* * *}$ & $1.21 \pm 0.06^{* *}$ \\
\hline \multirow{2}{*}{16} & $\mathrm{~S}(1.0 \mathrm{ml})$ & $94 \pm 12$ & $52 \pm 14$ & $269 \pm 14$ & $6.60 \pm 0.15$ & $3.56 \pm 0.85$ & $3.04 \pm 0.09$ & $1.17 \pm 0.03$ \\
\hline & PS $(1.0 \mathrm{~m} l)$ & $87 \pm 10$ & $44 \pm 7$ & $279 \pm 11$ & $7.10 \pm 0.04 * * *$ & $3.71 \pm 0.70$ & $3.38 \pm 0.08 * * *$ & $1.10 \pm 0.05^{*}$ \\
\hline
\end{tabular}

a) S: Physiological saline, PS: Porcine serum. T.P.: Total protein, Alb: Albumin, Glb: Globulin, A/G: Albumin/globulin ratio. $*: P<0.05, * *: P<0.01, * * *: P<0.001$ relative to the control group (Student's $t$-test).

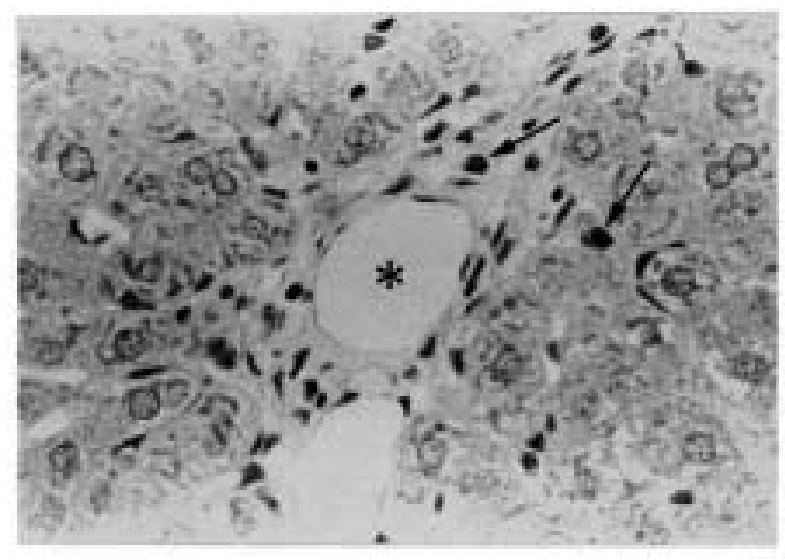

Fig. 1. Perivenular fibrosis and cellular infiltration including macrophages containing lipofuscin (arrows). 5th week postinitial injection (p.i.) (Experiment I). Asterisk: central vein (CV). Schmorl reaction. $\times 910$.

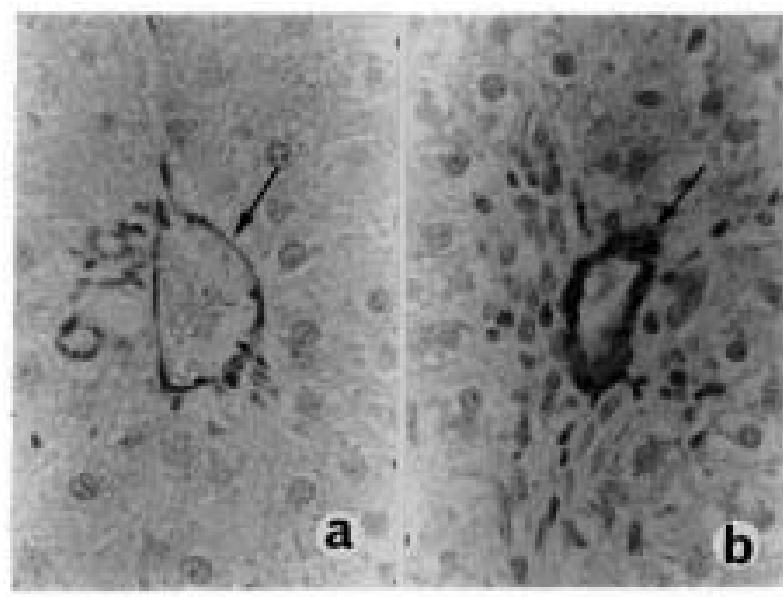

Fig. 3. Portal vein branches (arrow) in the same site of the left lateral lobe from a) control rat liver and b) treated rat liver with narrowing lumen. 8th week p.i. (Experiment II). Immunostain with anti- $\alpha$-SMA antibody and Mayer's hematoxylin counterstain. $\times 910$.

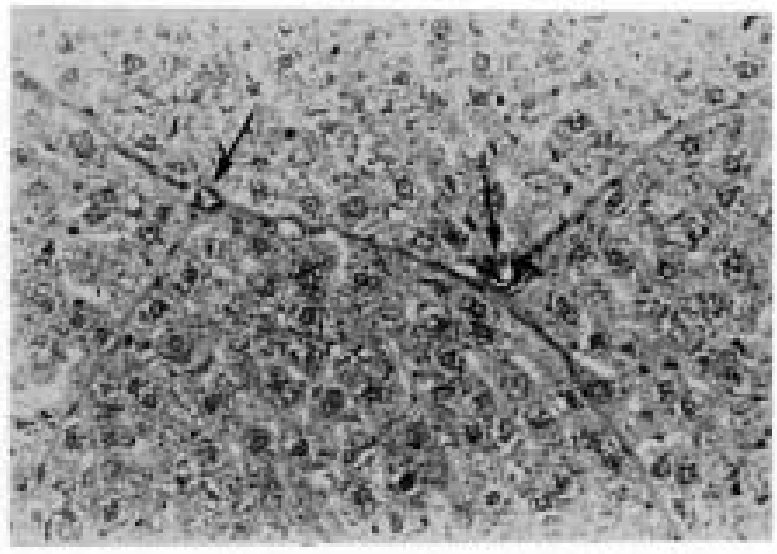

Fig. 2. Septal fibrosis bridging between CVs (arrows). 7th week p.i. (Experiment I). HE stain. $\times 460$.

essentially identical to those observed in 7-week-treated rat liver from Experiment I. The number of mast cells appeared to increase in proportion to the volume of collagen in the FS, but varied from area to area. Interlobar comparison showed that the extent of fibrosis in each rat tended to be strongest in the left lateral lobe and weakest in the right lateral lobe.

In Experiment III, the FS were wider and perivenular fibrosis was more evident than those of 8-week-treated rats at the same dose of PS in Experiment II. The degree of fibrosis was also more severe than that of the rats in Experiment II (Table 3). In Experiment III, the fibrosis occurred uniformly in all treated rats. In addition, hepatocellular changes such as necrosis/apoptosis (Fig. 4a), eosinophilic change (Fig. 4b) or fatty change (Fig. 4c), and proliferation of biliary ductules were frequently observed in the treated rats of Experiments III, but rarely observed in the treated rats in Experiment II. Areas of most advanced fibrosis (Grade 4, showing especially thick bands of collagen fibers) were abundant in elastic fibers varying in size (Fig. 5). 


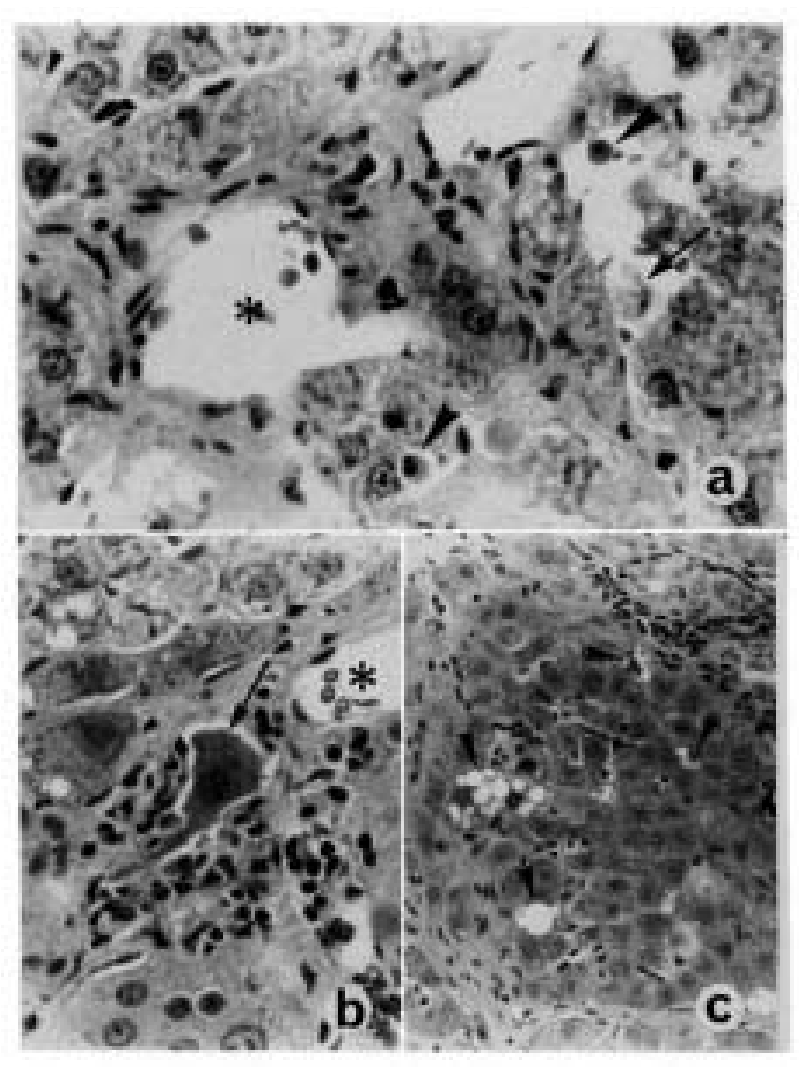

Fig. 4. a) Apoptotic (arrowheads) and deciduous hepatocytes (arrow) around central vein (*). b) Hepatocyte showing eosinophilic change and cellular reaction (arrow). c) Hepatocytes showing fatty change (arrowheads). a-c) 16th week p.i. (Experiment III). HE stain. a, b) $\times 910$. c) $\times 460$.

No anisonucleosis, cellular atypia, or swelling of hepatocytes were observed in any group throughout all three experiments.

Mild follicular hyperplasia in the spleen was observed histologically in PS-treated rats of all experiments but there was no significant difference in degree of follicular hyperplasia among the treated groups.

Immunohistochemistry: Alpha-smooth muscle actin $(\alpha-$ SMA)-and desmin-positive cells appeared in the early FS (Fig. 6a). In late stage FS, almost all spindle cells showed triple positive reactions for $\alpha$-SMA (Fig. 6b), desmin (Fig. $6 \mathrm{c}$ ), and vimentin. Desmin immunoreactivity was higher in cells in and adjacent to the FS than in Ito cells within the hepatic lobules (Fig. 6c). However, $\alpha$-SMA expression was limited to spindle cells around the CVs and in the FS and vascular SMCs. Vimentin expression was observed in all mesenchymal cells in the liver and proliferative biliary ductules. Most macrophages around the CVs and in the early and late stage FS showed positive reactions for both ED-1 (Fig. 6d) and ED-2. Vascular endothelial cells in the FS expressed factor VIII-related antigen (FVIII-RAg) (Fig. 6e), although sinusoidal endothelial cells (SECs) within the lobules were negative for this antigen. There was no significant difference in the number of PCNA-positive

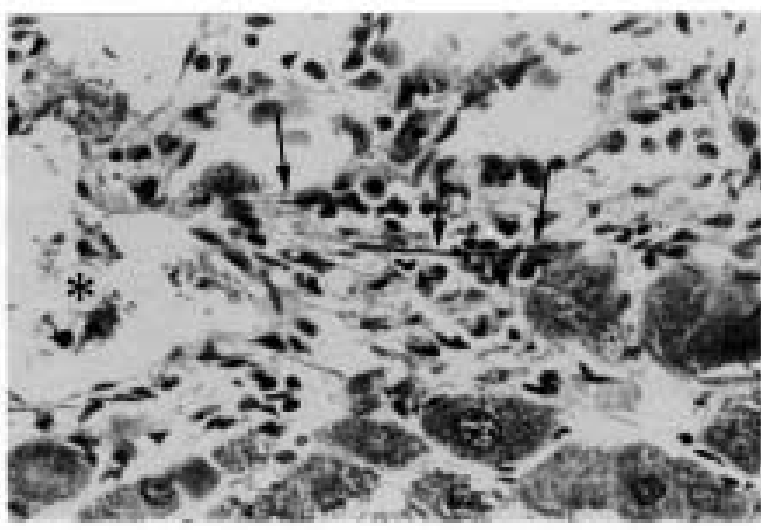

Fig. 5. Many elastic fibers varying in size (arrows) around CV $(*)$. 16th week p.i. (Experiment III). Orcein stain. $\times 910$.

heptocytes between control (LI: $0.68 \pm 0.20 \%$ ) and 16-weektreated $(0.76 \pm 0.15 \%)$ rat livers. Proliferative biliary ductules contained a high number of PCNA-positive cells. No PCNA-positive cells were observed in the FS.

Electron microscopy: Electron microscopic observation revealed that Ito cells (Fig. 7), fibroblasts, lymphocytes, plasma cells, lipofuscin- and/or hemosiderin-laden macrophages were present around the CVs and in the FS. Although only rarely observed, vascular endothelial cells in the FS had fenestrae accompanied by basement membranes, and were surrounded by Ito cells (Fig. 8). Occasionally, erythrocytes were observed in the Disse's space (Fig. 9a) and in the cytoplasm of hepatocytes around CVs (Fig. 9b). These ultrastructural findings were detected in all livers showing Grades 2, 3 and 4 fibrosis but were most prevalent in Grade 4 fibrosis.

\section{DISCUSSION}

The pathogenesis of PS-induced rat liver fibrosis has yet to be clarified. There were no relationships among the dose of PS, the extent of fibrosis, and the anti-PS antibody titer in the present study. However, a correlation between the latter two factors has been described previously [27]. Biochemical analysis revealed increased serum globulin in treated rats in the present study, but the role of host immunoreaction against PS in the pathogenesis of this fibrosis model is still unclear. The class of immunoglobulins produced or the volume of immune complexes may have some relationship to this pathogenesis.

A number of macrophages with and without lipofuscin around CVs and in FS in the present study were considered to be Kupffer cells because of their immunoreactivity to both ED-1 and ED-2. The lipofuscin in these cells may be derived from phagocytosed hepatocytes with lipid peroxidation of the plasma membranes.

Ito cells of rats are desmin-positive [38]. In the present study, the immunoreactivity for anti-desmin antibody of Ito cells around CVs and in and adjacent to FS was more intense than that of Ito cells within the lobules, as previously 


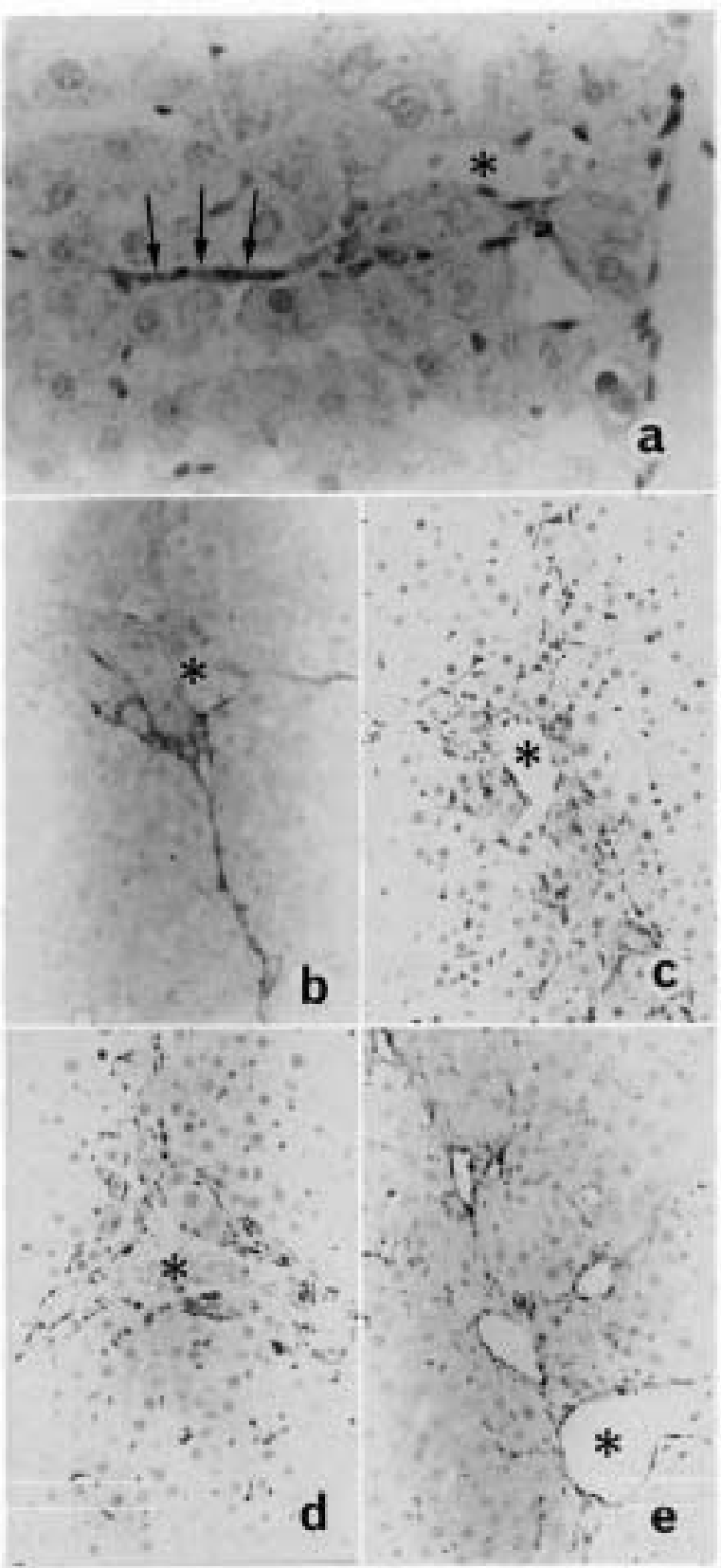

Fig. 6. Immunostain for cells around CV (*). a) $\alpha$-SMApositive cells (arrows, early stage), 5th week p.i. (Experiment I). × 910. b) a-SMA-(late stage), c) desmin-, d) ED-1-, e) FVIII-RAg-positive cells. Counterstained with Mayer's hematoxylin. b-e) 8th week p.i. (Experiment II). $\times 460$.

reported [7, 39]. Since Ito cells have shown an enhanced expression of desmin around damaged areas in the rat liver [25], presence of desmin-positive cells around CVs and in FS seen in the present study may represent a cellular reaction against hepatic injury in this model.

Septal fibroblasts in this model have been reported to be $\alpha$-SMA-negative [8], but we detected $\alpha$-SMA expression of

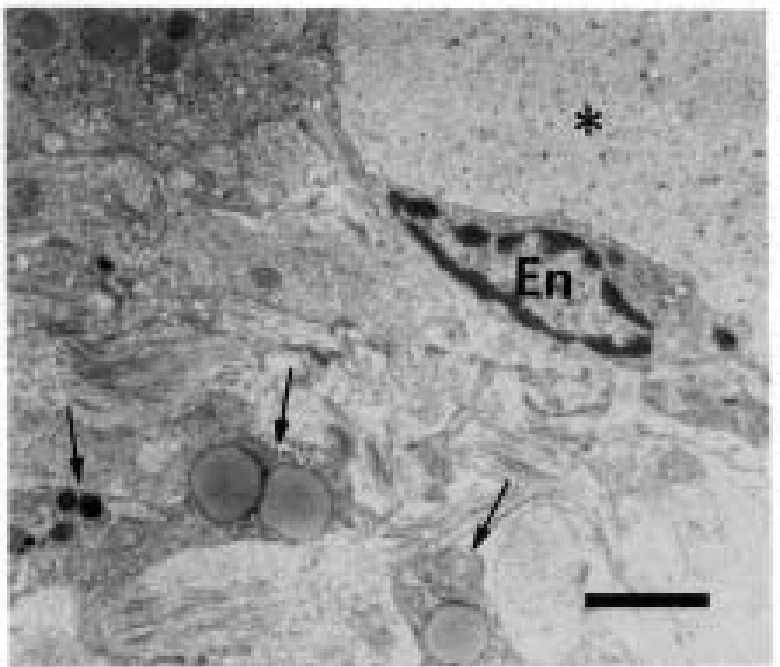

Fig. 7. Ito cells (arrows) around central vein $(*)$. 8th week p.i. (Experiment II). Electronmicrograph, stained with uranyl acetate and lead citrate. En: endothelial cell, Bar $=2 \mu \mathrm{m}$.

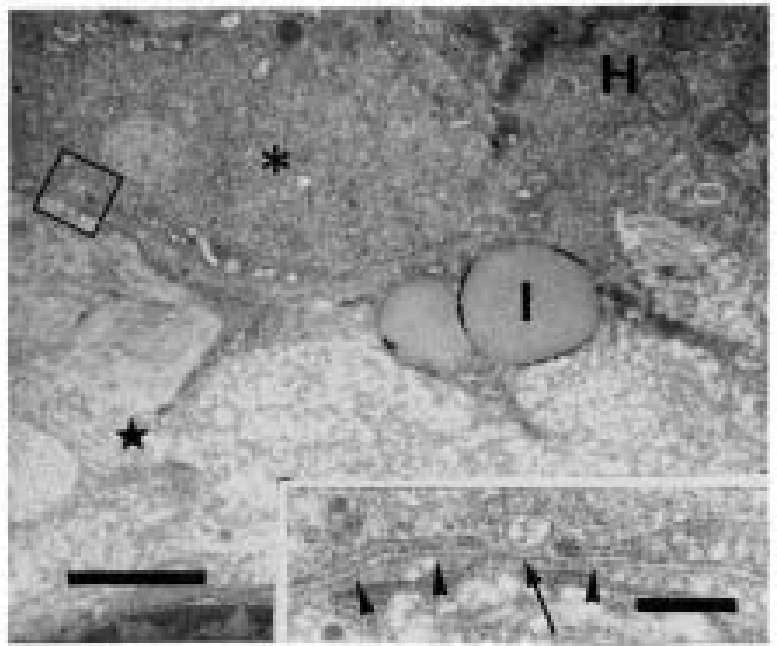

Fig. 8. Sinusoid $(*)$ in the fibrous septa (star), surrounding by Ito cell (I). inset: high power view of open black square showing the preservation of fenestration (arrow) and the basement membrane formation (arrowheads). 16th week p.i. (Experiment III). Electronmicrograph, stained with uranyl acetate and lead citrate. $\mathrm{H}$ : hepatocyte, Bar $=2 \mu \mathrm{m}$, (inset) $0.5 \mu \mathrm{m}$.

the septal fibroblasts in the present study as seen in $\mathrm{CCl}_{4}$ induced liver fibrosis [24, 30, 34]. However, no myofibroblast-like cells were observed in FS in the present study, just as none were observed in previous studies on PS-induced liver fibrosis in rats $[1,3,7,20,31]$. Ito cells in the areas of necrosis in human chronic active hepatitis have shown an increased intensity of immunostaining for $\alpha$-SMA [11]. As in the case of desmin-expression, $\alpha$-SMAexpression may also represent a reactive change in Ito cells in response to hepatocellular necrosis. Transformation of 


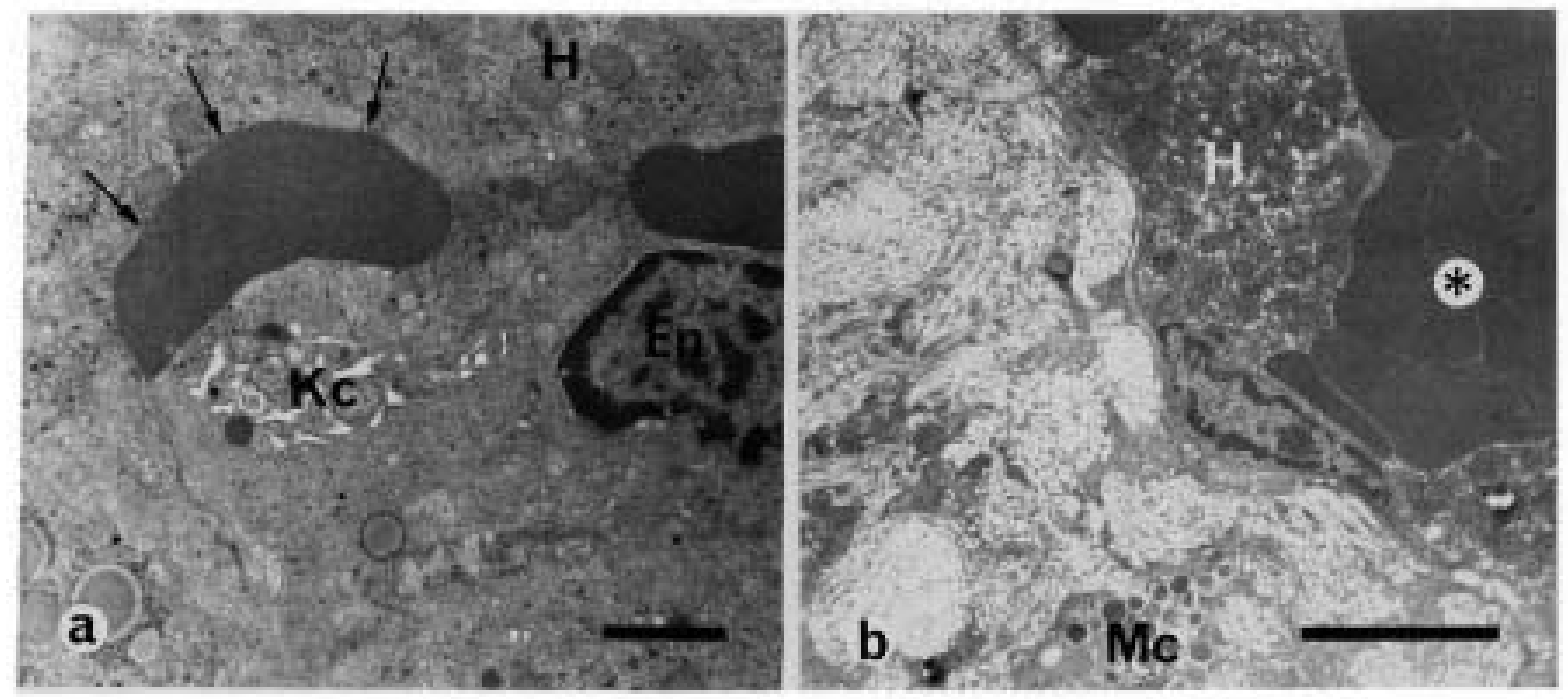

Fig. 9. a) Influx of erythrocyte (arrows) into the Disse's space, 8th week p.i. (Experiment II). b) Presence of erythrocytes $(*)$ in the cytoplasm of hepatocyte, 16th week p.i. (Experiment III). Electronmicrograph, stained with uranyl acetate and lead citrate. H: hepatocytes, Kc: Kupffer cell, En: endothelial cell, Mc: mast cell, Bar = a) $2 \mu \mathrm{m}$, b) $5 \mu \mathrm{m}$.

rat Ito cells into myofibroblasts has been demonstrated in vitro [30, 37] and in vivo [34].

Hepatic fibrosis develops on account of incomplete hepatocellular regeneration following hepatocellular necrosis. Although the significance of hepatocellular necrosis in the liver fibrogenesis has been proposed by Popper [29], the PS-induced liver fibrosis model has been characterized by absence of an obvious hepatocellular necrosis [27]. In general, several findings such as presence of $\alpha$-SMA -positive cells [11], desmin-positive cells [25], and macrophages $[14,16]$, and proliferation of elastic fibers [33] in the liver have been considered to be the results of hepatocellular necrosis. These findings were also observed in the present study, suggesting that hepatocellular necrosis/ apoptosis developed in PS-treated rat liver and those changes were undetectable by light microscopy in the 8-week-treated rats because of a small number of injured cells and rapid phagocytosis by macrophages. Hepatocellular necrosis/ apoptosis and degeneration were observed frequently in the 16-week-treated rat liver in the present study and these results may indicate an elevated frequency of hepatocellular injury.

It has been reported that hemosiderin-loaded macrophages appear around $\mathrm{CVs}$ at an early stage in $\mathrm{CCl}_{4}$-induced rat liver fibrosis [30]. Ultrastructural study on dichloropropanol-induced acute hepatic necrosis revealed large gaps between SECs along with extravasation in conjunction with hepatocellular degeneration [13]. Hemosiderin in Kupffer cells in the present study may be derived from extravasated erythrocytes resulting from hepatocellular injury of endothelial damage inducing hyperpermeability.

Mast cell and eosinophil infiltration were frequently encountered around CVs and in FS in the present study. Mast cells are known to affect fibroblast activity [10]. A correlation may exist between collagen production and the accumulation of mast cells and eosinophils in PS-induced liver fibrosis in rats [31]. A single intraperitoneal injection of Ascaris cuticle induced eosinophilia, mast cell hyperplasia, and antibody production in rats [2]. Therefore, frequent infiltration of both types of cells in PS-induced liver fibrosis may indicate the occurrence of some kind of immunoreaction in the liver, but their significance is not known at present.

Presence of erythrocytes in the cytoplasm of hepatocytes and in the Disse's space was occasionally demonstrated around CVs and adjacent to FS in the present study. Since hypoxia due to circulatory disturbance in the liver accelerates the pinocytotic activities of the hepatocytes [36], these findings may indicate the presence of hypoxic conditions in hepatocytes located between neighboring $\mathrm{CVs}$ in this model.

The endothelial cells expressing FVIII-RAg in FS may be SECs as suggested by ultrastructural findings in this study. Increased arterial blood supply in small hepatocellular carcinoma resulted in expression of FVIIIRAg in the SECs and sinusoidal capillarization [19]. FVIII-RAg expression in the SECs of FS in this model may indicate increased blood flow into the liver. These hemodynamic changes may develop as an adaptive phenomenon against altered intrahepatic circulation in this model.

Partial obstruction of the portal vein induced apoptosis of hepatocytes and resulted in atrophy of the left and median lobes and compensatory hypertrophy of the right and caudate lobes of the liver [17]. Interlobar differences in the extent of fibrosis were found in the present study. This concurrence in the distribution of lesions and the development of early FS from CVs near the hepatic capsule may suggest that fibrogenesis in this model followed the 
vascular or hemodynamic changes in intrahepatic circulation.

In conclusion, hepatocellular necrosis/apoptosis develops in PS-treated liver fibrosis in rats, and may result from an adaptation to hemodynamic changes in the liver.

ACKNOWLEDGEMENTS. We thank Dr. Makoto Enomoto (Biosafety Research Center, Foods, Drugs, and Pesticides, Shizuoka, Japan) for reviewing this manuscript, and Dr. Jiro Sugimoto (Mitsubishi Chemical Corp., Yokohama Research Center, Yokohama, Japan) for biochemical analysis.

\section{REFERENCES}

1. Andrade, Z. 1991. Contribution of the study of septal fibrosis of the liver. Int. J. Exp. Pathol. 72: 553-562.

2. Archer, G. T., Coulits, N., Jindra, J., and Robson, J. E. 1985. Eosinophilia, mast cell hyperplasia and antibody production in rats following an intraperitoneal injection of Ascaris cuticle including in vitro studies of immune eosinophil granule lysis. Pathology 17: 101-107.

3. Ballardini, G., Esposti, S. D., Bianchi, F. B., De Giolgi, L. B., Faccani, A., Biolchini, L., Busachi, C. A., and Pisi, E. 1983. Correlation between Ito cells and fibrogenesis in an experimental model of hepatic fibrosis: A sequential stereological study. Liver 3: 58-63.

4. Ballardini, G., Faccani, A., Fallani, M., Berti, S., Vasi, V., Castaldini, C., Biagini, G., Garbisa, S., and Bianchi, F. B. 1985. Sequential behavior of extracellular matrix glycoproteins in an experimental model of hepatic fibrosis. Virchows Arch. B Cell Pathol. 49: 317-324.

5. Ballardini, G., Fallani, M., Biagini, G., Bianchi, F. B., and Pisi, E. 1988. Desmin and actin in the identification of Ito cells and in monitoring their evolution to myofibroblasts in experimental liver fibrosis. Virchows Arch. B Cell Pathol. 56: 45-49.

6. Bhunchet, E. and Fujieda, K. 1993. Cappillarization and vascularization of hepatic sinusoids in porcine serum-induced rat liver fibrosis: A mechanism to maintain liver blood flow. Hepatology 18: 1450-1458.

7. Bhunchet, E. and Wake, K. 1991. Origin of the septal fibroblastic cells in the pig-serum-induced fibrosis in the rat liver. pp. 207-210. In: Cells of Hepatic Sinusoid, vol. 3 (Wisse, E. et al. eds.), Kupffer Cell Foundation, The Netherland.

8. Bhunchet, E. and Wake, K. 1992. Role of mesenchymal cell populations in porcine serum-induced rat liver fibrosis. Hepatology 16: 1452-1473.

9. Cenacchi, G., Ballardini, G., De Giorgi, L. B., Busachi, C. A., Del Rosso, M., Bianchi, F. B., Biagini, G., and Laschi, R. 1983. Relationship between connective tissue cells and fibronectin in a sequential model of experimental hepatic fibrosis. Virchows Arch. B Cell Pathol. 43: 75-84.

10. Claman, H. N. 1985. Mast cells, T cells and abnormal fibrosis. Immunol. Today 6: 192-195.

11. Enzan, H., Himeno, H., Iwamura, S., Saibara, T., Onishi, S., Yamamoto, Y., and Hara, H. 1994. Immunohistochemical identification of Ito cells and their myofibroblastic transformation in adult human liver. Virchows Archiv 424: 249-256.

12. Fujiwara, K., Ogata, I., Ohta, Y., Hayashi, S., Mishiro, S., Tatsuki, K., Sato, Y., Yamada, S., Hirata, K., Oka, H., Oda,
T., Kawaji, H., Matsuda, H., Niijima, Y., and Tsukuda, R. 1988. Decreased collagen accumulation by a prolyl hydroxylase inhibitor in pig serum-induced fibrotic rat liver. Hepatology 8: 804-807.

13. Haratake, J., Furuta, A., and Hashimoto, H. 1994. Immunohistochemical and ultrastructural study of hepatic sinusoidal linings during dichloropropanol-induced acute hepatic necrosis. Liver 14: 90-97.

14. Hines, J. E., Johnson, S. J., and Burt, A. D. 1993. In vivo responses of macrophages and perisinusoidal cells to cholestatic liver injury. Am. J. Pathol. 142: 511-518.

15. Ishida, N., Nakata, K., Tanaka, M., and Mita, S. 1991. The protective effects of SA 3443, a novel cyclic disulfide, on chronic liver injuries in rats. J. Hepatol. 13: 200-207.

16. Johnson, S. J., Hines, J. E., and Burt, A. D. 1992. Macrophage and perisinusoidal cell kinetics in acute liver injury. $J$. Pathol. 166: 351-358.

17. Kerr, J. F. R. 1971. Shrinkage necrosis: A distinct mode of cellular death. J. Pathol. 105: 13-20.

18. Kimura, H., Kako, M., Fujiwara, K., Torii, M., and Oda, T. 1979. Electron microscopic studies on experimental hepatic fibrosis induced by pig serum.J. Clin. Electron Microscopy 12: 5-6.

19. Kin, M., Torimura, T., Ueno, T., Inuzuka, S., and Tanikawa, K. 1994. Sinusoidal capillarization in small hepatocellular carcinoma. Pathol. Inter. 44: 771-778.

20. Kitamura, K., Yasoshima, A., Iwasaki, H. O., Kojima, A., Doi, K., and Okaniwa, A. 1984. Hepatic fibrosis produced in rats by repeated intraperitoneal injections of swine serum. Jpn. J. Vet. Sci. 46: 265-271.

21. Miao, S., Bao-En, W., Annoni, G., Esposti, S. D., Biempica, L., and Zern, M. A. 1990. Two rat models of hepatic fibrosis: A morphological and molecular comparison. Lab. Invest. 63: 467-475.

22. Montfort, I., Perez-Tamayo, R., Alvizouri, A. M., and Tello, E. 1990. Collagenase of hepatocytes and sinusoidal cells in the reversibility of experimental cirrhosis of the liver. Virchows Arch. B Cell Pathol. 59: 281-289.

23. Nakano, M. 1986. Early morphological changes of porcine serum- induced hepatic fibrosis. Acta Pathol. Jpn. 36: 415432.

24. Nouchi, T., Tanaka, Y., Tsukada, T., Sato, C., and Marumo, F. 1991. Appearance of $\alpha$-smooth-muscle-actin-positive cells in hepatic fibrosis. Liver 11: 100-105.

25. Ogawa, K., Suzuki, J., Mukai, H., and Mori, M. 1986. Sequential changes of extracellular matrix and proliferation of Ito cells with enhanced expression of desmin and actin in focal hepatic injury. Am. J. Pathol. 125: 611-619.

26. Okuno, M., Muto, Y., Kato, M., Moriwaki, H., Noma, A., Tagaya, O., and Tanabe, Y. 1991. Changes in serum and hepatic levels of immunoreactive prolyl hydroxylase in two models hepatic fibrosis in rats. J. Gastroent. Hepatol. 6: 271277.

27. Paronetto, F. and Popper, H. 1966. Chronic liver injury induced by immunologic reactions: cirrhosis following immunization with heterologous sera. Am. J. Pathol. 40: 10871101.

28. Paronetto, F. and Popper, H. 1965. Aggravation of hepatic lesions in mice by in vivo localization of immune complexes (Auer hepatitis). Am. J. Pathol. 47: 549-563.

29. Popper, H. 1977. Pathologic aspects of cirrhosis. Am. J. Pathol. 87: 228-264.

30. Ramadori, G., Veit, T., Schwögler, S., Dienes, H. P., Knittel, 
T., Rieder, H., and Meyer zum Buschenfelde, K.-H. 1990. Expression of the gene of the $\alpha$-smooth muscle-actin isoform in rat liver and in rat fat-storing (ITO) cells. Virchows Arch. B Cell Pathol. 59: 349-357.

31. Ramos, S. G., Montenegro, A. P., Goissis, G., and Rossi, M. A. 1994. Captopril reduces collagen and mast cell and eosinophil accumulation in pig serum-induced rat liver fibrosis. Pathol. Inter. 44: 655-661.

32. Rubin, E., Hutterer, F., and Popper, H. 1968. Experimental hepatic fibrosis without hepatocellular regeneration. Am.J. Pathol. 52: 111-119.

33. Scheuer, P. J. and Lefkowitch, J. H. 1994. Acute viral hepatitis. pp. 62-80. In: Liver Biopsy Interpretation, 5th. ed., W. B. Saunders Company Ltd., London.

34. Schmitt-Gräff, A., Chakroun, G., and Gabbiani, G. 1993. Modulation of perisinusoidal cell cytoskeleton features during experimental hepatic fibrosis. Virchows Arch. A Pathol.
Anat. 422: 99-107.

35. Senoo, H. and Wake, K. 1985. Suppression of experimental hepatic fibrosis by administration of vitamin A. Lab. Invest. 52: 182-194.

36. Takano, A., Shibayama, Y., and Nakata, K. 1984. The morphogenesis of the vacuolation of liver cells. Liver 4: 97-104.

37. Tsutsumi, M., Takada, A., and Takase, S. 1987. Characterization of desmin-positive rat liver sinusoidal cells. Hepatology 7: 277-284.

38. Yokoi, Y., Namihisa, T., Kuroda, H., Komatsu, I., Miyazaki, A., Watanabe, S., and Usui, K. 1984. Immunohistochemical detection of desmin in fat-storing cells (Ito cells). Hepatology 4: 709-714.

39. Yokoi, Y., Namihisa, T., Matsuzaki, K., Miyazaki, A., and Yamaguchi, Y. 1988. Distribution of Ito cells in experimental hepatic fibrosis. Liver 8: 48-52. 